Carmichael, James V. and Marilyn L. Shontz. (January, 1996) "`The Last Socially Acceptable Prejudice:' Gay and Lesbian Issues, Social Responsibilities and Coverage of These Topics in MLIS/MLS Programs." The Library Quarterly 66: 21-58. Made available courtesy of University of Chicago Press: http://www.jstor.org/stable/4309088

***Reprinted with permission. No further reproduction is authorized without written permission from the University of Chicago Press.***

\title{
THE LAST SOCIALLY ACCEPTABLE PREJUDICE: GAY AND LESBIAN ISSUES, SOCIAL RESPONSIBILITIES, AND COVERAGE OF THESE TOPICS IN M.L.I.S./M.L.S. PROGRAMS ${ }^{1}$
}

\author{
James V. Carmichael, Jr., and Marilyn L. Shontz ${ }^{2}$
}

A survey of 465 U.S. (90.5 percent) and Canadian (9.5 percent) 1993 graduates of master's (M.L.I.S. and M.L.S.) programs accredited by the American Library Association (ALA) addressed lesbigay issues within the context of professional social responsibilities. Specifically, graduates were asked to agree or disagree with thirty-three statements reflecting attitudes toward (1) the ALA position on social responsibility as manifested in official professional documents such as the ALA Library Bill of Rights; (2) multiculturalism and political correctness; (3) the status of women in librarianship; (4) gay and lesbian issues in librarianship; and (5) the treatment these topics received in their M.L.I.S. and M.L.S. programs. Extensive personal data were also solicited, including the subjects' selfidentified political orientation, sexual orientation, personal acquaintance with AIDS victims, educational background, and job history. Responses and openended comments indicated that library and information studies and library and information professionals are not ideologically cohesive in their views on women's issues, lesbigays, or the relationship between social responsibilities and professionalism. The findings of the study, although not definitive, would seem to justify more exhaustive studies on the demographic and ideological identity of library and information professionals.

1. We wish to thank the following individuals without whose help the study could not have been completed: the deans and contact personnel of participating programs; Paul Adams, Tricia Goodman, and Kathleen Powers, graduate assistants at the University of North Carolina at Greensboro, who helped with mailings and input of data; Wayne A. Wiegand, University of Wisconsin-Madison, for encouragement and support; Alvin M. Schrader, University of Alberta, Edmonton, for help with Canadian mailings; and Marilyn L. Miller, Chair, University of North Carolina at Greensboro, for use of the department's resources.

2. Department of Library and Information Studies, University of North Carolina at Greensboro, Greensboro, North Carolina 27412-5001.

[Library Quarterly, vol. 66, no. 1, pp. 21-58]

(C) 1996 by The University of Chicago. All rights reserved.

0024-2519/96/6601-0001\$01.00 
Background and Literature Review: Lesbigay ${ }^{3}$ Concerns in Librarianship

While the Public Library Inquiry found in 1952 that public librarians were middle-class individuals with conservative to moderate social views [1], since the social upheavals of the $1960 \mathrm{~s}$, the belief has persisted within the profession that a sizable portion of its members are politically democratic and socially liberal [2, pp. 65-83]. This view is seemingly reinforced by what now appears to have been intense civil rights activism in the areas of racism, feminism, and homosexuality in the early $1970 \mathrm{~s}$ [3], yet in reality American Library Association (ALA) leadership and library educators have rarely championed the rights of lesbigay clients or colleagues, and the profession is far more ambiguous on social issues than its democratic philosophy would lead one to believe. Martha Boaz, for example, former dean of the Library School at the University of Southern California, wrote in 1971 [4] that gays and lesbians should be excluded from the social responsibility credo of librarians, and her sentiments have been echoed in recent years in letters printed in the "Reader's Forum" column of American Libraries, following publication of a cover photograph of lesbigay librarians marching in the 1992 San Francisco Gay Pride Day Parade (for example, [5; 6, cover]).

Ironically, ALA was the first professional organization to form a task force to address gay concerns (now called the Gay, Lesbian, and Bisexual Task Force, or GLBTF), ${ }^{4}$ which has been in part responsible for the promotion and growth of a market in lesbigay literature through such annual recognitions as the Gay and Lesbian Book Award [7; 8, s.v. "Libraries and Archives," by Wayne R. Dynes]. At the same time, discussion of lesbigay issues has been confined to programs of the GLBTF. Only one or two general studies to date have queried librarians on gay

3. There is no consensus on the proper terminology for nonheterosexual persons, or agreement on what homosexuality is, even within the lesbigay community. "Gay" now usually applies to male homosexuals, and "lesbians" to female homosexual persons. However, some homosexuals, in seeking to empower themselves, have reclaimed the labels used to demean them over the years ("fag," "dyke," and "queer"), while some people prefer the generic "gay" to apply to all nonheterosexuals. "Lesbigay" is a concise portmanteau word that incorporates bisexuals with gays and lesbians; this term is used throughout this article except when speaking of gays, lesbians, or bisexuals specifically, a practice that seems warranted by the adoption of the name "Gay, Lesbian, and Bisexual Task Force" for the professional task force within the American Library Association in 1995.

4. Formed as the Task Force on Gay Liberation in 1970 (shortly thereafter, the Gay Task Force), the name of the group was changed to the Gay and Lesbian Task Force in 1986, and to the Gay, Lesbian, and Bisexual Task Force in 1995. 
issues, and virtually nothing has been written on lesbian or bisexual librarians' concerns ([9] does not discuss lesbian librarians; [10] and [11] are rare examples). It is fairly easy to ascertain that the partitioning of lesbigay issues from "acceptable" social responsibility charges to the category of "special interests" has been consistent over the years, since the Social Responsibilities Roundtable is only a year older than GLBTF and is, in fact, the parent organization of GLBTF. At the same time, it is hardly accidental that GLBTF had to petition council for six years before ALA would sponsor the Gay and Lesbian Book Award (first awarded by ALA in 1986) [7, p. 15].

As Polly Thistlethwaite surmises, the history of lesbigay librarians in the United States is still largely "hidden" [12, s.v. "Gays and Lesbians in Library History," by Polly Thistlethwaite]. By way of contrast, in New Zealand, where homosexuality has been decriminalized throughout the country and the national gay archives are housed in the national library, Phil Parkinson [13] has provided notable examples of "probably" gay nineteenth-century bibliophiles who served the British Empire with distinction. Thus, even while changing perceptions of sexual orientation frustrate attempts to understand it historically, pioneering efforts such as Parkinson's provide professional role models for gay and straight librarians. Examples of lesbigay librarian role models are simply not available to American lesbigays, especially since American library biography is largely male-oriented, asexual, and two-dimensional (a notable exception is [14]; see [15] for discussion of problems). Lesbigay history is silenced by social taboos and by the overprotective efforts of surviving relatives and friends to protect the reputation of self-documenting lesbigays or to save themselves future embarrassment by destroying lesbigay letters, diaries, and memorabilia [16].

Librarianship, as a service profession in which women have constituted from 70.5 to 90 percent of the workers since 1876 , has remained curiously impervious to general and dispassionate discussion of gender issues, and particularly lesbigay issues. Other feminized service professions such as nursing and teaching have been quick to recognize the relationship between homophobia and the general complex of gender problems in the workplace $[17,18]$, but librarianship has tended to relegate philosophical discussion of lesbigay issues, which it equates with political issues, to "alternate" library literature. The exception to this rule is a small corpus of popular library literature concerning lesbigay clients, lesbigay literature, and bibliographic concerns such as pejorative bias in subject headings (for example only: [9; 19-21;22, pp. 110-12]).

A profession that supports such documents as the "Freedom to Read Statement" and "The Library Bill of Rights" should make informed 
decisions about lesbigay issues within the profession and with respect to the library's public, not from an artificial stance of political correctness, but because homophobia, which is historically related to sexism and racism [23, 24], ${ }^{5}$ contradicts basic tenets of equality of access and service. While lesbigay issues may directly affect only a small portion of the population-from 1 to 8 percent according to the most recent estimates $[25$, p. $139 ; 26$, pp. 1-12]-they have general relevance to the entire society. Moreover, it is exactly because lesbigays form such a small minority of the population that their interests, welfare, and civil liberties demand closer attention. Most important, if librarian researchers choose not to study the lives of lesbigays in their ranks, someone may do it for them anyway: sociologist Christine Williams [27], for example, discusses gays in librarianship, nursing, social work, and elementary school teaching in her study of men in female professions.

The relative complacency of librarians toward gender inequities has been noted by the Committee on the Status of Women in Librarianship [28], and the degree of gender denial in librarianship [29] no doubt has considerable bearing on the absence of attitude surveys concerning lesbigay issues, and the obliqueness of studies bearing on lesbigay professional rights in the library community. Lesbigay concerns have been recognized already by professional associations as academically diverse as the American Medical Association (AMA) and the American Historical Association (AHA). The AMA banned discrimination based on sexual orientation in 1993; the AHA, however, finds that such professional policies may in fact carry little weight in the workplace, according to a 1993 survey that reported incidents of workplace discrimination from colleagues, students, and/or administrators among 70 percent of lesbigay AHA member-respondents [30, 31]. Although ALA Council has affirmed its support for lesbigay library workers in the ALA Policy Manual (see secs. 54.17 and 54.7 particularly), the programs and activities of GLBTF have received almost no attention in published discussions of professional meetings within ALA during the 1980s, and minimal historical discussion (see, for example, [3]). Among library educators, writings and research on lesbigay issues have been practically nonexistent. Recently, attention to sexual abuse of students by professors has escalated in the media [32] and reflects in part the prejudice that exists against lesbigay educators in schools [18, pp. 142-44, 161-62, 230-31]. The latter phenomenon exacerbates the already marginal situation of

5. Jessie Daniel Ames spoke out especially against the southern lynchings which were carried out supposedly to protect the "honor" of southern white women, for African American women had borne the sexual assaults of southern white males since slavery had been instituted. The hypocritical southern system in fact disempowered all women, African American women as well as white women-the enthroned "diadems of Dixie." 
lesbigay faculty because of the corollary stereotyping of the sexual behavior of lesbigay faculty as more promiscuous than that of straight colleagues. Sexual issues on campus are exceedingly complex in the best of times, and the lesbigay dimension in the current environment of student "victimization" injects shades of meaning that most researchers are happy to avoid.

Although ALA has been organizationally "progressive," it has lacked visible spokespersons for the lesbigay minority at top levels, and discussions of lesbigay issues have been confined to special interest meetings. To date, only Dorothy Broderick has gone public as a lesbian (former) library school educator committed to open discussion of lesbigay issues within the classroom and without, and she has remained remarkably consistent in her views since she first addressed the subject in 1974 $[33,34]$. She challenged the "hypocrisy" of the Intellectual Freedom Committee in 1974 for failing to champion the sensational case of J. Michael McConnell, a University of Michigan library employee who was fired after he applied with his male lover for a marriage license: "Supposedly the library and the university are the two institutions in society most concerned with maintaining and expanding society's concepts of freedom. Yet consistently they make it clear that only hypocrites are acceptable. Be gay, but be quietly gay" [35, p. 32]. ${ }^{6}$

Lesbigay issues resurfaced at the national level in 1992-93 because of an unprecedented degree of open debate in the popular press [36$39],{ }^{7}$ and for only the second time in ALA history, a library educator publicly defended the rights of lesbigays to protest discrimination; a month after President Bill Clinton announced a lifting of the ban on gays in the military in December 1992, ALA President Marilyn Miller made a speech at a march on the Denver, Colorado, capitol to protest the passage of the state's discriminatory Amendment Two. Her statement embraced both the bibliographic and humanistic ideals of librarianship, and she was unequivocal in her insistence on active protest: "We know how the line can blur between access to information and denial of our human rights. . . . Any erosion of human liberty can lead to an erosion of intellectual freedom" [40]. It was shortly after Miller's speech

6. Broderick went on to state that she taught in Canada to avoid discrimination in U.S. library education programs, and averred that she would "never buy the position" of the Intellectual Freedom Committee since its only concern was "the abstraction of preventing the oppression of ideas, and my concern is with the reality of preventing oppression to people" [35, p. 39].

7. Henry L. Gates, Jr., points out that the African American backlash against lesbigays who compare their struggle to the Civil Rights movement is ironic, given the fact that the organizer of the first Civil Rights march, Bayard Rustin, was prevented from being named the march's director in 1963 because it was feared that his homosexuality would discredit the movement's aims. 
that the current research project was planned. The Denver decision was not a popular one, nor was the relocation to Philadelphia (for similar reasons) of the 1995 Cincinnati midwinter meeting, which occurred shortly after plans for the current research project were under way. These events provided the professional context within which the current study was conducted.

\section{Project Objectives}

The purpose of this study was to assess the attitudes of 1993 library school graduates on lesbigay issues within the context of professional social responsibilities. Prejudice against lesbigays is "the last socially acceptable prejudice," according to Tom Gaughan, who defended American Libraries' 1992 cover photograph of lesbigay librarians in the Gay Pride Day Parade in a subsequent editorial [41], and exclusive attention is given to that issue in this report, although our study also covered related issues. Graduates of 1993 were selected as the population because their attitudes about social issues were assumed to reflect the end result of their formal professional education; as many of them had only been on their jobs a short while (and many were still searching for jobs), their ideas might be expected to be reflective of their education rather than bound by workplace attitudes. While the survey instrument could have been focused exclusively on lesbigay issues, we felt that the response rate would be augmented by an instrument that inquired about attitudes toward lesbigay issues within more general social concerns. The study measures the relationship between social responsibilities issues in the curriculum of recent M.L.I.S./M.L.S. graduates in their library and information studies (LIS) education, and their current attitudes toward selected social issues-sexual orientation, women/gender issues, "political correctness," legal redress for minorities, and the relative importance of social responsibilities in the library and information profession. The focus of the present report, sexual orientation, is perhaps the most volatile of the issues listed and is long overdue for consideration given the lack of research studies that have accompanied the editorial polemic on the issue in the past few years.

Specifically, are the attitudes of lesbigay librarians toward professional and social issues, and especially lesbigay issues, any different than those of their straight cohort? Is sexual orientation a valid predictor of attitudes toward social responsibilities issues, and, specifically, lesbigay issues, or are there other factors that are more useful indicators (for example, age, sex, library type)? Most important, what role does an M.L.I.S./M.L.S. program play in shaping the attitudes of students to- 
ward social issues? What is the approach to social issues in the curricula of M.L.I.S./M.L.S. programs?

The results of the survey are intended to assist in identifying the attitudes of people the profession is attracting, the extent of instruction they are receiving in library education programs with regard to social responsibility issues, and what effect, if any, that instruction has had on their personal outlook. This information may be used to inform continuing discussion of social responsibility issues in the curriculum, as well as indicate to the profession what degree of consensus exists among the current and future generations of library and information professionals.

\section{Methodology}

\section{Project Description}

With the assistance of deans/directors of the programs, questionnaires and personal data forms were mailed to a randomly selected sample of 7931993 graduates of programs accredited by ALA's Committee on Accreditation (COA) in March 1994. At the completion of the survey time line in July, data analysis began. Analysis included calculation of statistical relationships between attitude scores reflected on questionnaire items and the factors of age, sex, race, sexual orientation, social orientation, personal knowledge of a person who had died of AIDS, and library type; detailed comparisons between the lesbigay and straight, and female and male, graduates; and a qualitative analysis of open-ended comments. It should be noted that at the time that the survey was mailed, ALA's Gay and Lesbian Task Force had not yet included the term "bisexual" in its title. Therefore lesbigay items on the survey employed the terminology "gays and lesbians."

In October 1993 the survey instrument (see Appendix) was pretested among class members of an LIS research methods course at the University of North Carolina at Greensboro (UNCG), among selected 1992 graduates of the UNCG M.L.I.S. program, and among selected members of the UNCG Jackson Library staff, to verify construct and face validity of the instrument. Adjustments in wording, clarification, and design of the instrument were made in response to comments received from the forty-three pretest subjects.

The population chosen for this study was all 1993 calendar-year master's degree graduates of fifty U.S. and seven Canadian library and information studies programs accredited by ALA/COA. A stratified proportional sample of 20 percent of the 1993 graduates was randomly 
selected from all programs that were currently accepting new students. ${ }^{8}$ In January 1994 deans and directors of each program were contacted by mail. The purpose of the study was explained and their participation in the project requested. Each dean/director was asked to identify a contact person and to supply the total number of calendar-year 1993 graduates stratified by sex. Program directors were also provided a checklist to indicate whether they wished to participate in the survey or not and, if so, whether they preferred to mail out the surveys from the school. In the latter case, stamped and coded surveys with selfaddressed stamped envelopes (SASEs) were mailed to the program contacts with instructions for drawing the sample. Otherwise, the contact person was given information concerning random selection of the needed number of participants and was asked to return to us a list of selected graduates with addresses. Phone calls were placed to all schools not returning the initial data sheet in the enclosed SASE.

In order to obtain a randomly selected stratified sample, we assigned progressive letters of the alphabet to each school and asked contact persons to provide the names and addresses of 20 percent of graduates in strict alphabetic order beginning with an assigned alphabet letter (for example, "r"). By assigning a different letter to each program, randomness was achieved and alphabetic bias avoided. Fifteen programs did not participate in the survey, and the total number of surveys representing 20 percent of 1993 graduates in the other forty-two programs totaled 793. When all lists had been received, surveys were coded and mailed to all respondents on the list (and, in nine cases, to the program directors for distribution), along with a letter explaining the purposes of the survey and an SASE.

Because of delays caused by the negotiation process with programs that chose to mail their own surveys, and the fact that mailings to schools subsequently had to be staggered throughout March and early April, the cutoff date for data collection was pushed back to July 1, 1994. A follow-up mailing was sent to all respondents who had not returned their survey one and a half months from the date of the first mailing with a second SASE. Upon receipt, objective responses were coded for computer entry, all open-ended comments were recorded and coded, and a note was made of those respondents who wished to receive a copy of results.

Of 793 surveys mailed out, 465 usable responses were received ( 58.64 percent). Only those surveys that were accompanied by completed per-

8. Northern Illinois University and Brigham Young University, still listed in the COA brochure "Graduate Library Education Programs, March 1993," were not accepting new master's degree students in 1993. 
sonal data sheets were considered usable, since one of the aims of the study was to relate personal factors with expressed attitudes in response to statements on the questionnaire. Thirty-seven surveys (4.67 percent) were returned because the recipient had moved with no forwarding address, and 291 persons ( 36.70 percent) did not return surveys at all. One person left a message on our answering machine stating that she did not wish to participate in the survey and requested strongly that a follow-up request not be sent. It seemed obvious from the nature and tone of her comments that she did not approve of the subject of the survey. Other comments, discussed below, were received from a few persons who provided extensive critiques of the design and purposes of the survey, whether or not they answered all survey questions.

\section{Other Problems Encountered}

In addition to the normal problems encountered with tracking graduates who had no forwarding addresses or those who chose not to participate, program nonparticipation created some geographic imbalances. One of the purposes of the survey was to gather as wide a range of data as possible, and equal regional representation based on the number of schools listed in the Association for Library and Information Science Education (ALISE) directory and currently accepting new students (sixteen programs in the Northeast; thirteen in the Southeast; eleven in the Midwest; five in the Southwest; five in the West; and seven Canadian programs, for a total of fifty-seven programs). Programs did not participate for a variety of reasons: five programs did not respond at all to our initial and follow-up requests; five programs cited university regulations prohibiting the disclosure of graduate names and addresses, or the participation in surveys; three programs pleaded lack of adequate staff to draw the required sample, and one program explained that graduate records were in the process of being reorganized. One Canadian program declined to participate on the basis of the then upcoming October 1994 legislation that would prohibit use of "private records" to cull the necessary names and addresses. Thus, out of a total of fifty-seven M.L.I.S. and M.L.S. programs, fifteen did not participate, which resulted in some regional disproportions. Of the fifteen programs, four were in the Northeast, four were in the Midwest, three were in the West, three were in Canada, and one was in the Southeast. The resulting regional representation of programs was, Northeast, twelve programs; Midwest, seven programs; Southeast, twelve programs; Southwest, four programs; West, three programs; and Canada, four programs. In this final group, western programs particularly were underrepresented, and the Southwest was the only region in which all programs participated. In light of the fact that states like California, and particularly urban 
centers like San Francisco and Los Angeles, have lesbigay-friendly reputations, lesbigay respondents may be underrepresented in the present sample. Again, however, there are no data to support the idea that there are necessarily more lesbigay library students in western programs than elsewhere.

\section{Statistical Analysis}

Frequencies, percentages, and means were calculated for all items, with difference between means and analysis of variance (ANOVA) performed on all questionnaire items except 8 and 31 (relating to particular courses) using the Statistical Package for the Social Sciences (SPSS) at the probability level $P<.05$. A potential problem in data analysis lies in the switch from category-level data (forced-choice responses) to interval data (means). We believed this switch was justified because of the large number of cells and the number of empty cells resulting from chi-square calculations. The demographic factors used for comparison were age, sex, sexual orientation, social orientation, region of school, and acquaintance with an AIDS victim. For this report, data are arranged in tabular format for the total sample by sexual orientation only. Regional summaries were prepared for participating M.L.I.S./M.L.S. programs but are not included in this report. In the discussion below, significant statistical relationships are reported for selected factors, and detailed descriptive analysis is provided for the sample as a whole, and for lesbigays as compared to the straight cohort.

\section{Demographic Profile of the Sample}

The resulting sample presented a familiar profile, in spite of the fact that not all respondents completed all sections of the personal data form (see table 1). Slightly over three-quarters of the sample ( 76.3 percent) was female. Nearly 84 percent of graduates were forty-five years or younger, and the largest segment (31.6 percent) was between twentyone and twenty-nine years of age. The sample was predominantly white ( 87.1 percent), in a proportion higher than the 75.90 percent reported for full-time male and female AL.A-accredited master's degree students in the 1993 ALISE Report [42, pp. 123-29], due no doubt to the fact that ALISE tallies foreign-born students separately. ${ }^{9}$ The close approxi-

9. The ratio of Hispanic ( 3 percent) and Native American ( 3 percent) graduates is higher for the sample than total figures reported by ALISE ( 1.86 percent and $>1$ percent, respectively), while that for African Americans (3 percent) and Asian Americans (2.2 percent) is slightly lower than the ALISE percentages ( 3.83 percent and 2.92 percent). The survey did not solicit information regarding nationality, although twenty-three respondents ( 4.9 percent) indicated that they were foreign-born and thirty-three other (7.1 percent) did not provide place of birth. 
TABLE 1

Demographic Profile of 1993 Graduates by Sexual Orientation, Personal, and Employment Data

\begin{tabular}{|c|c|c|}
\hline Characteristic & Straight & $\begin{array}{c}\text { Gay/Lesbian/ } \\
\text { Bisexual }\end{array}$ \\
\hline \multicolumn{3}{|l|}{ Sex: } \\
\hline Male & $93(21.7)$ & $15(45.5)$ \\
\hline Female & $334(78.0)$ & $18(54.5)$ \\
\hline No response & $1 \quad(.2)$ & $\cdots$ \\
\hline \multicolumn{3}{|l|}{ Age: } \\
\hline $21-29$ & $137(32.2)$ & $8(24.2)$ \\
\hline $30-35$ & $87(20.4)$ & $7(21.2)$ \\
\hline $36-39$ & $43(10.1)$ & $7(21.2)$ \\
\hline $40-45$ & $86(20.2)$ & $8(24.2)$ \\
\hline $46-49$ & $43(10.1)$ & $\cdots$ \\
\hline $50-55$ & $24 \quad(5.6)$ & $3 \quad(9.1)$ \\
\hline 56 or older & $6 \quad(1.4)$ & $\cdots$ \\
\hline \multicolumn{3}{|l|}{ Marital status: } \\
\hline Single & $188(43.9)$ & $20(60.6)$ \\
\hline Married & $218(50.9)$ & $4(12.1)$ \\
\hline With partner & $22(5.1)$ & $9(27.3)$ \\
\hline \multicolumn{3}{|l|}{ Race: } \\
\hline White & $376(88.7)$ & $27(81.8)$ \\
\hline Hispanic & $14 \quad(3.3)$ & $\cdots$ \\
\hline African American & $14 \quad(3.3)$ & $\cdots$ \\
\hline Asian American & $8 \quad(1.9)$ & $1 \quad(3.0)$ \\
\hline Native American & $5 \quad(1.2)$ & $3 \quad(9.1)$ \\
\hline Other & $7 \quad(1.7)$ & $2(6.1)$ \\
\hline \multicolumn{3}{|l|}{ Social orientation: } \\
\hline Radically progressive & $21 \quad(5.0)$ & $8(24.2)$ \\
\hline Liberal & $197(46.5)$ & $14(42.4)$ \\
\hline Moderate & $156(36.8)$ & $9(27.3)$ \\
\hline Conservative & $49(11.6)$ & $2(6.1)$ \\
\hline Radically conservative & $1 \quad(.2)$ & $\ldots$ \\
\hline \multicolumn{3}{|l|}{ Knew AIDS victim: } \\
\hline Yes & $141(33.2)$ & $22(68.8)$ \\
\hline No & $284(66.8)$ & $10(31.3)$ \\
\hline \multicolumn{3}{|l|}{ Library type: } \\
\hline Academic & $95(22.6)$ & $6(18.2)$ \\
\hline Public & $113(26.8)$ & $13(39.4)$ \\
\hline SLM* & $51(12.1)$ & $1 \quad(3.0)$ \\
\hline Special & $50(11.9)$ & $5(15.2)$ \\
\hline Non-LIS & $45(10.7)$ & $5(15.2)$ \\
\hline None & $43(10.2)$ & $3 \quad(9.1)$ \\
\hline Other & $24 \quad(5.7)$ & $\ldots$ \\
\hline \multicolumn{3}{|l|}{ Position: } \\
\hline Administration & $17 \quad(5.4)$ & $2 \quad(6.3)$ \\
\hline Adult services & $22 \quad(7.0)$ & $1 \quad(4.2)$ \\
\hline Youth services & $26 \quad(8.2)$ & $1 \quad(4.2)$ \\
\hline Reference & $110(34.8)$ & $9(37.5)$ \\
\hline
\end{tabular}


TABLE 1 (Continued)

\begin{tabular}{lrcc}
\hline \hline Characteristic & Straight & $\begin{array}{c}\text { Gay/Lesbian/ } \\
\text { Bisexual }\end{array}$ \\
\hline Other public services & $9(2.8)$ & $1(4.2)$ \\
Cataloging & $27(8.5)$ & $4(16.7)$ \\
Acquistions & 4 & $(1.3)$ & $1(4.2)$ \\
Other technical services & $8(2.5)$ & $1(4.2)$ \\
Collection development & $9(1.3)$ & $\ldots$ \\
SLM* specialist & $46(14.6)$ & $1(4.2)$ \\
Other & $43(13.6)$ & $3(12.5)$ \\
\hline
\end{tabular}

Nore.-Total usable responses received: 465 , four graduates did not indicate their sexual orientation, however. Percentages are given in parentheses. Response to each item varied; percentages are based on number of responses for each characteristic. - School library media.

mation of the figures to these national data allowed us to surmise that the sample was representative of the sex/racial/age profile of American and Canadian programs as a whole.

Not all graduates were familiar with standard questionnaire techniques. One person refused to fill out any part of the personal data sheet and asked, "How is this any of your business?" Potentially, the most controversial item on the personal profile was sexual orientation, yet only four respondents (slightly less that 1 percent) failed to mark it. In standard surveys, subjects are not usually asked for this information as it is considered to be threatening, even given the standard assurances of research confidentiality or anonymity. We reasoned, however, that since lesbigay literature has repeatedly called for routine collection of demographic data on the lesbigay community (for example, [43, pp. 86-89]), those subjects who were comfortable with their sexuality would not hesitate to indicate their sexual orientation. At least one other survey in the field of librarianship has solicited such data with no apparent anomalies [44]. While some underreporting of sexual orientation might be expected among new professionals as a matter of course, it seems self-evident that some comparative data on lesbigays is better than none at all. In the present survey, 8 percent of respondents indicated lesbigay status, a figure comparable to the standard Kinsey estimate, using the expanded definition of sexual orientation to include bisexuals.

Given the changing social climate, it is difficult to interpret what new adjustments the marital status classifications entail: for example, while 43.9 percent of the straight sample indicated their marital status as "single," as did 60.6 percent of the lesbigay sample, 12.1 percent of the lesbigay sample indicated that they were married, as opposed to 27.3 percent who chose the category "with partner." Whether this finding indicates that those four lesbigay individuals who described themselves 
as married actually live in a heterosexual marriage while engaging in same-sex activities or inclinations, or whether they have been joined by religious ceremony into a monogamous relationship with a same-sex partner, is not clear. Even sociologists have not determined the best way to classify people along the sexual orientation continuum, although various models have been proposed [ $26 ; 45$, pp. 135-38; 46, pp. 23764]. At any rate, over a third (39.4 percent) of the lesbigay respondents indicated that they are married or living with a partner, as compared to 56 percent of straight respondents who report being married (50.9 percent) or living with a partner (5.1 percent). Given the lack of legal and social sanctions for same-sex unions [47, pp. 224-69], the discrepancy between marital status figures for straight and lesbigay respondents is perhaps not surprising.

As an indicator of sensitiveness to medical issues affecting the lesbigay community in particular over the past decade, respondents were asked whether they had known anyone who had died of AIDS. This item was also construed as an indicator of persons more likely to have a greater "forced" personal awareness of AIDS, and consequently to have a greater understanding of current social problems generally, of which discrimination against lesbigays is only one. Roughly a third of the total sample (35.5 percent) responded affirmatively. As expected, the proportion of lesbigays who had known a deceased AIDS victim was over twice as great as that for straight respondents $(68.8$ percent and 33.2 percent, respectively).

A second indicator of social attitude was provided on the personal data sheet by a forced-choice classification of social orientation on the liberal-conservative scale, using loosely labeled "loaded" terminology: radically progressive, liberal, moderate, conservative, or radically conservative. We recognized that the terms might not precisely describe social or political orientation for every individual-especially since their definitions nationally are variable - but that respondents had the opportunity to place themselves along a relative scale of labels associated with social attitudes. It is not surprising that the majority described themselves as either "liberal" (45.8 percent) or "moderate" (35.7 percent), positions somewhere in between the extremes of radically progressive (6.2 percent), radically conservative ( 0.02 percent $)$, or conservative ( 11.0 percent), but leaning toward the liberal end of the spectrum. The two "liberal" categories comprise 52 percent of sampled graduates, while "conservative" categories describe only 11.2 percent. As might be expected, a much greater proportion of lesbigay subjects selected the "radical liberal" category ( 24.2 percent, as compared to only 5 percent of the straight sample), while two-thirds of lesbigays (66.6 percent) chose either liberal category compared to 51.5 percent of the straight sample. 
The library type and position of 1993 graduates responding to this survey bear out news of recent professional trends in the growth of user services and reference work resulting from the proliferation of networks, remote-site services, and increased demand placed on reference and interlibrary loan personnel due to expanded database access. The greatest proportion of sampled 1993 graduates were working in public (27.3 percent) or academic (22.2 percent) libraries, and over a fourth (26.2 percent) were engaged in some form of reference work, with an additional 2.2 percent engaged in other public service work such as interlibrary loan. More lesbigays (6.3 percent) than straight respondents (5.4 percent) were engaged in some kind of administrative work, although taken together these individuals account for only 4.1 percent of the total sample. Perhaps inevitably, more women (25.6 percent) than men ( 6.4 percent) are school media specialists or youth services librarians. Also, the ratio of straight school media specialists (14.6 percent) and youth services librarians ( 8.2 percent) is greater than that for lesbigays (4.2 percent each), although it is impossible to determine from current data whether lesbigays prefer not to work in youth services fields or whether they feel discouraged from doing so. Nearly twice as many lesbigays ( 16.5 percent) as straights (8.5 percent) work as catalogers. Possible reasons for these occupational choices have been offered elsewhere [44, pp. 425-27], yet market forces may play a greater role than preference in the current economic climate, since at the time of this survey, nearly 10 percent of respondents had no job at all, and several wrote lengthy comments voicing their distress at the lack of jobs. One young woman even solicited help in obtaining a job. Along with her survey, she sent us a résumé and an appeal for help, although she announced in a subsequent letter that she had just landed a desirable position in a state agency.

Other data that enabled us to draw a more complete picture of the sampled 1993 graduates were education and employment history and educational background. Over three-quarters of the graduates were already national professional association members, and, while slightly over 86 percent had begun and completed their degree work in the last four years, sixty-one respondents had been working on their degrees since before 1990, and one had begun course work in 1981. Most had little or no professional experience, although over 37 percent of respondents who answered the work experience portion of the survey had worked as a paraprofessional from two to five years before entering a library education program. There were rare examples of longstanding service to an institution before obtaining the degree: one person had worked in a professional position for twenty years, while another had worked as a paraprofessional for twenty-three years. 
Graduates changed their interests in particular types of libraries for a variety of reasons, although no reason was so prevalent as the unstable job market. Over a quarter of the sample worked in a different type of agency than they had initially planned to when entering an M.L.I.S./ M.L.S. program. The qualitative comments indicated that job availability was the most prevalent reason for changing library type. Other general reasons for changing directions were course work, changing impressions-such as a negative practicum experience in a law library cited by one respondent-and a spiritual calling to work in a particular denominational college.

The disciplinary choices of this sample, as indicated by undergraduate, second master's, and doctorate degrees, confirmed findings about the educational background of M.L.I.S./M.L.S. students. Nearly 20 percent of the sample had obtained a master's degree before entering an M.L.I.S./M.L.S. program, and another seven individuals had earned a second master's. Only eleven individuals had obtained a doctorate, while twenty-eight subjects had earned other degrees (associate degree or law degree, for example). The majority of graduates obtained their degrees in the humanities or social sciences (classifications used were those listed in [48, pp. 15-28]). ${ }^{10}$ The master's major area followed the same pattern, with education, social science, performing arts, and letters accounting for the greatest number of degrees, and in the second master's category, only marketing and philosophy/religion were new to the list. As for lesbigays, nearly twice as great a proportion earned undergraduate degrees in the performing arts compared to the straight cohort. A greater percentage of lesbigays held master's degrees in education, performing arts, and philosophy and religion.

\section{Methodological Concerns Based on Respondent Comments}

Respondents completed the Likert-scale questionnaire consisting of thirty-three statements covering general attitudes toward social responsibility issues in the profession and society (items 1, 2, 4, 9, 21, 27, 30); diversity and political correctness (items $11,13,18,26$ ); women's issues in society and in the profession, including legal redress for inequities (items 12, 16, 23, 25, 33); gays and lesbians in society and in the profession (items 6, 10, 20,22, 24, 32); coverage of gays and lesbians in the library media (items $7,14,15,19,28$ ); and treatment of social responsibilities, women's issues, and gay and lesbian issues in the curriculum of M.L.I.S./M.L.S. programs (items 3, 5, 8, 17, 29, 31). Items 8 and 31

10. The largest groups represented were letters (21.6 percent), social science (20.9 percent), education (13.9 percent), performing arts (9.3 percent), and communications and psychology (4.6 percent each). 
asked respondents to specify courses where they had learned about social responsibilities and gay and lesbian issues.

At the outset, it should be noted that a few criticisms, sometimes severe, were received from some respondents concerning the design and construction of the questionnaire. Whereas we had purposefully intended certain items to embody attitudes representative of those current in the editorial columns of American Libraries, the mainstream press, and the talk-show-host circuit in an effort to elicit spontaneous reactions to controversial social issues statements, some respondents resented what they interpreted as bias, ambiguity, and unclear language (for example, "political correctness," and "professional") and questioned items that had been slightly rephrased elsewhere on the questionnaire or recast as negative statements (for example, items 15 and 19). It was quite clear from the open-ended responses received that some respondents were thoroughly satiated with discussion of multiculturalism, political correctness, women's issues, and lesbigay issues in society at large, in the media, and in the library and information profession. At the same time, some responses also indicated that these issues had not received serious study in library literature or consistent coverage in M.L.I.S.I M.L.S. curricula. A few Canadian respondents were offended that the questionnaire they received was not translated into French, while several Canadian respondents expressed confusion over items referring to the First Amendment to the U.S. Constitution.

The most strongly worded criticism addressed what was perceived by a respondent as a failure on our part to make the intentions of the survey more clear.

I do not think any attempt was made to create an unbiased survey. The use of such phrases as "editorial backlash in the professional community" and the way some of your questions are worded damage the integrity of your study. As researchers and library educators I would hope you would have learned these basics in you own library education. I also think you should have defined "social responsibilities of librarians." My social responsibility as a librarian is to provide equal access and service regardless of race, color, sexual orientation, ethnic group, content of question, etc. If you are going to do a study on gay and lesbian issues, then do that and be direct about your intentions-not biased. If you need help, call the research professor that I had on research methods in librarianship ... or ask any student other than the ones you have taught.

While at least one lesbigay research study advocated self-disclosure in interviews [43, pp. 91-92], there is no evidence to suggest that such a tactic works better or worse in formal mailed questionnaires, particularly in the preliminary stages, although one of the authors was privately counseled by a former doctoral adviser that the categories "gay" and "lesbian" should be flatly avoided on questionnaires as that would nega- 
tively affect any response rate. Perhaps self-disclosure should be actively and openly practiced in all research on lesbigay issues. It is not a practice that is currently being followed, however, by many leading lesbigay researchers, perhaps because most studies focus on lesbigays whose identity is already known, or whose participation has been solicited through lesbigay listservs, mailing lists, or focus groups. ${ }^{11}$ The purpose of the present survey was different, however, since it sought to compare responses of various subgroups of the general population to a variety of issues of which lesbigay issues were only a part. Equally important was the whole complex of attitudes surrounding the current professional social responsibilities debate, for which lesbigay issues may serve as a symbol.

Some respondents fretted over the use to which the survey data would be put. The most extensive of these gave a detailed chronicle of imperialistic U.S. policies and indifference to suffering abroad; he considered the triviality of the subject of the present survey would reinforce still more denial of and indifference to the world problem, and he declined to participate. Others worried about anonymity or misunderstood the purpose of having coded surveys (namely, for follow-up purposes). The codes on two returned questionnaires were removed, while one person circled the code and noted that "this kind of thing lowers the response rate."

Several respondents also worried about the lack of a truly neutral response such as "don't know" or "no opinion" on the survey form. At least one respondent failed to answer three items and marked "I don't know" next to each item, and one returned blank survey was accompanied by a letter that explained that being a recent graduate disqualified her from "judging" social issues. Short of providing an even more attenuated list of options or a true forced-choice questionnaire, we believed that "both agree and disagree" reflected the nature and degree of ambiguity evident in conversations about these issues with colleagues and students. A decision was therefore made to interpret at least some measure of agreement with the statements as partially supportive of them, given that they are statements reflective of attitudes, not statements of fact; given that some statements are phrased negatively and some positively; and given that the respondent would agree with the statement in at least some circumstances. In some cases, that interpretation may not be correct, so that readers should be aware of possible overreporting

11. In 1993, for example, noted southern gay sociologist James $T$. Sears sent a survey on the status of lesbigay education faculty to selected individuals at southeastern universities and asked them to circulate the questionnaire to other lesbigay faculty members with whom they were acquainted. 
on these issues and balance the interpretation with open-ended comments received.

A more serious problem related to the response "not discussed at all" in items 8 and 31 relating to coverage of social issues in specific courses, which some respondents apparently skipped over, leaving the entire item blank. Apparently, they did not read the item carefully enough to realize that there was a space to indicate noncoverage; using hindsight, that part of the item should have been a separate item entirely. Still another problem related to the terminology of course titles: "technical services" is not employed in many programs, for example, and "foundations"-type courses exist under many different guises, from "The Library in Society" to "Issues in Librarianship." In reporting which courses covered social responsibilities issues and lesbigay issues, we have made an attempt to determine the nature of the course, collapse courses into appropriate categories, and preserve the integrity of unique course titles where appropriate.

\section{Findings}

\section{Lesbigay Issues in the Profession}

Six items called for responses to statements reflecting attitudes about lesbigays in the profession (items $6,10,20,22,24,32$; see table 2). Four of these related to lesbigay library materials, and library policies regarding lesbigay materials (items $6,10,22,32$ ). Since these topics have been covered to a small extent in library literature, it was assumed that they were more likely to have been discussed in M.L.I.S./M.L.S. courses. Moreover, they were issues with which graduates may have had firsthand experience, whether or not they were acquainted with any openly lesbigay individuals. Two other items related to the perception of the number of lesbigays in the profession (item 24) and the personal feelings of respondents toward lesbigay issues and literature (item 20).

Less than a fifth of respondents (18.5 percent) agreed or strongly agreed that there was a higher percentage of lesbigays in the profession than in society at large, and $\mathbf{4 0 . 8}$ percent disagreed or strongly disagreed with this statement. This finding reflects either knowledge or opinion on the part of respondents, since to date there is no empirical evidence that would support the notion that there is a larger proportion of lesbigays in the library profession than in other professions, or than in the general population, although that view occasionally surfaces [10], and in some locales may be accurate.

Twenty-four individuals (5.20 percent) disagreed "strongly" with gay and lesbian literature on principle, and would not buy it for a library unless demand warranted such an action. Another thirty-six "disagreed" 
with this item while sixty-seven "both agreed and disagreed." In other words, a total of 12.9 percent of the sample either disapproved of nonheterosexual ideology entirely, or at least the lesbigay literature they had seen. This persistence of negative reactions to lesbigay literature is understandable, since a large part of lesbigay expression was confined for many years to "underground" or pornographic literature. The majority of mainstream lesbigay history, sociology, and fiction only began to appear about twenty-five years ago; the proliferation of university publishing in this area has flourished only in the past decade, and only in the past few years have Gale Research (Book Review Index), Information Access Company and University Microfilms (both electronic format), and the Modern Language Association Bibliography included lesbigay titles in their lists of indexed periodicals [49]; as of June 1995 the $\mathrm{H}$. W. Wilson Company indexes do not include mainstream lesbigay periodical titles in spite of petitions over the last five years from the GLBTF's Indexing Project to include the Advocate, BLK, Gay Community News, the Lesbian News, Out/Look, and OutWeek in Readers' Guide to Periodical Literature. Therefore, it can be assumed that at least some part of this "hostile" group of respondents were simply unaware of the variety and depth of lesbigay titles now available, that at least a part of them had an ideological stance that was not inclusive of lesbigays, and that some shared both reservations about the topic. ${ }^{12}$

Certainly the most controversial books in the past few years were Heather Has Two Mommies and Daddy's Roommate, titles that opened up new avenues of discussion on alternative parenting. The authors included a statement about these titles since it seemed likely that most recent graduates would be familiar with the numerous challenges the books have received in libraries. More than three-quarters of respondents (79.6 percent) agreed or strongly agreed that they would acquire these titles for a public library if they were the best titles of their type available. A smaller proportion of graduates (64.9 percent) agreed or strongly agreed that lesbigay issues should be addressed through collection development in all areas of the library. As to how lesbigay materials-here labeled "controversial"-should be handled in communities where there is a strong antigay sentiment, only 5.8 percent of the sample unequivocally agreed that lesbigay materials should be sequestered (that is, kept off open shelves) in communities where there is a strong antigay sentiment, while 81.1 percent unequivocally disagreed. Only 6.9 percent of respondents agreed with sequestering when the caveat "to prevent theft or defacement" was added to the statement.

Lesbigays were more likely than straight subjects to advocate compre-

12. The statement of this item was flawed in that it asked for perceptions on two separate issues, a defect that did not surface in pretesting. 
TABLE 2

Mean Scores and Differences by Sexual Orientation Responses to Social Responsibility Survey

\begin{tabular}{|c|c|c|c|c|c|}
\hline Question & $\begin{array}{l}\text { Total } \\
\text { Mean } \\
\text { Score }\end{array}$ & $\begin{array}{l}\text { Straight } \\
\text { Mean } \\
\text { Score }\end{array}$ & $\begin{array}{l}\text { Straight } \\
\text { Difference }\end{array}$ & $\begin{array}{l}\text { Gay/Lesbian/ } \\
\text { Bisexual } \\
\text { Mean Score }\end{array}$ & $\begin{array}{l}\text { Gay/Lesbian/ } \\
\text { Bisexual } \\
\text { Difference }\end{array}$ \\
\hline $\begin{array}{l}\text { 1. Professionals should remain aloof from social and political activism. } \\
\text { 2. The library profession is more socially progressive than most profes- }\end{array}$ & 3.72 & 3.71 & -.01 & 3.88 & +.16 \\
\hline $\begin{array}{l}\text { 3. My education in librarianship introduced me to the concepts of librari- } \\
\text { 3. }\end{array}$ & 2.64 & 2.68 & +.04 & 2.27 & $-.37 *$ \\
\hline ans' social responsibility. & 2.46 & 2.46 & .00 & 2.56 & +.10 \\
\hline 4. Libraries and librarians have a responsibility to address social issues. & 2.29 & 2.30 & +.01 & 2.15 & -.14 \\
\hline $\begin{array}{l}\text { 5. Women's issues received some special emphasis in my LIS curriculum. } \\
\text { 6. Materials on controversial topics such as gay and lesbian issues should } \\
\text { be sequestered (kept off open shelves) in communities where there is a }\end{array}$ & 3.53 & 3.55 & +.02 & 3.36 & -.17 \\
\hline $\begin{array}{l}\text { strong anti-gay sentiment. } \\
\text { 7. The library media distorts gay and lesbian issues within the library pro- }\end{array}$ & 4.18 & 4.17 & -.01 & 4.42 & +.24 \\
\hline $\begin{array}{l}\text { 9. Public libraries should adhere to the philosophy "something to offend } \\
\text { 9. }\end{array}$ & 3.38 & 3.38 & 0 & 3.36 & -.02 \\
\hline 10. Gay and lesbian issues should be addressed through collection develop- & 2.44 & 2.48 & +.04 & 2.03 & -.41 \\
\hline ment in all areas of the library (fiction, non-fiction, reference, etc.). & 2.06 & 2.11 & +.05 & 1.55 & $+.51^{*}$ \\
\hline $\begin{array}{l}\text { 11. "Political correctness" is a danger to freedom of speech. } \\
\text { 12. Affirmative Action/Equal Opportunity legislation has had a negative ef- }\end{array}$ & 2.47 & 2.44 & -.03 & 3.09 & $+.62 *$ \\
\hline $\begin{array}{l}\text { 13. There are just too many special interest groups and minority groups } \\
\text { The library and information professions. }\end{array}$ & 3.67 & 3.66 & -.03 & 3.91 & +.24 \\
\hline $\begin{array}{l}\text { competing for attention in our society. } \\
\text { 14. Within the library and information profession, the library media doesn't }\end{array}$ & 3.31 & 3.27 & -.04 & 3.91 & $+.60^{*}$ \\
\hline $\begin{array}{l}\text { pay enough attention to gay and lesbian issues. } \\
\text { 15. I would be offended by an American Libraries cover featuring openly gay }\end{array}$ & 3.49 & 3.52 & +.03 & 3.07 & $-.42^{*}$ \\
\hline $\begin{array}{l}\text { and lesbian librarians. } \\
\text { 16. Affirmative Action/Equal Opportunity legislation has had no discernible }\end{array}$ & 3.98 & 3.93 & -.05 & 4.58 & $+.60^{*}$ \\
\hline $\begin{array}{l}\text { effect on the library and information profession. } \\
\text { 17. Social responsibilities received some special emphasis in my LIS curricu- }\end{array}$ & 3.42 & 3.41 & -.01 & 3.61 & +.19 \\
\hline & 2.68 & 2.69 & +.01 & 2.64 & -.04 \\
\hline
\end{tabular}


18. The dangers of a philosophy of "political correctness" are greatly exaggerated by the media.

braries devoted to problems and concerns of gay librarians and library clients.

(1)

20. I disagree with the premise of pro-gay and -lesbian literature and would only purchase these titles if requested by members of the community.

21. Library and information professionals have adequately addressed social and political issues.

22. If I were responsible for collection development in a public library, I would have acquired children's titles dealing with gay and lesbian issues such as Heather Has Two Mommies and Daddy's Roommate-if they were the best titles of their type available.

23. Affirmative Action/Equal Opportunity legislation has had a positive effect on the library and information professions.

24. There is a higher percentage of gays and lesbians in the library and in formation profession than in the society at large.

25. Women's issues have received too much attention in library literature.

26. A philosophy of "political correctness" is essential for the protection of the rights of some minority groups.

27. Social activism is intrinsic to the exercise of First Amendment rights in a democratic society.

28. The library media pays too much attention to gay and lesbian issues in the library profession.

29. Multicultural diversity received some special emphasis in my LIS curriculum.

30. I was aware of librarians' social responsibility before entering an LIS program.

32. Library materials on controversial topics such as gay and lesbian issues should be sequestered to prevent theft or defacement.

$2.60 \quad 2.53$

33. Women's issues have not been adequately addressed by the library and information profession.

\begin{tabular}{lrrrr}
1.91 & 1.95 & +.04 & 1.52 & $-.39^{*}$ \\
2.76 & 2.79 & +.03 & 2.56 & -.20 \\
3.31 & 3.36 & +.05 & 2.94 & -.37 \\
3.84 & 3.84 & .00 & 4.09 & +.15 \\
3.27 & 3.29 & +.02 & 2.97 & -.30 \\
2.20 & 2.23 & +.03 & 1.94 & -.26 \\
3.40 & 3.37 & -.03 & 3.94 & $+.54^{*}$ \\
2.65 & 2.65 & .00 & 2.73 & +.08 \\
2.79 & 2.80 & +.01 & 2.70 & -.09 \\
4.02 & 4.02 & 0 & 4.00 & -.02 \\
3.16 & 3.17 & +.01 & 2.94 & -.22 \\
\hline
\end{tabular}

- Scatistically significant difference at probability level $P<.05$ 
hensive lesbigay coverage in the collection $(P=.0070)$, more likely to acquire titles like Heather Has Two Mommies and Daddy's Roommate $(P=$ .0449), and, quite naturally, were less likely than the straight cohort to disagree with the premise of lesbigay literature $(P=.0231)$.

\section{Lesbigay Issues in the Library Media}

Five statements addressed the coverage of lesbigay issues by library media (items $7,14,15,19,28$ ), and two of these items specifically targeted the recent controversy in the pages of American Libraries concerning a cover photograph of lesbigays marching in the 1992 San Francisco Gay Pride Day Parade (items 15 and 19). Only 11.6 percent of graduates agreed or strongly agreed that library media distorted lesbigay issues (item 7), while 41 percent disagreed or strongly disagreed. Only 13 percent unequivocally agreed that library media does not pay enough attention to lesbigay issues (item 14), and 17 percent unequivocally agreed that library media pay too much attention to them (item 28). Over half agreed or strongly agreed that they would not be affected one way or another by an issue of American Libraries devoted to problems and concerns of lesbigay librarians and library clients (item 19), while 15.9 percent would be offended by a cover of American Libraries that featured openly lesbigay librarians (item 15). Women were less likely than men to agree with the premise that the library media distorts lesbigay issues $(P=.0195)$. Lesbigays responded in a perhaps predictable manner to four of the items relating to library media: they were more likely to agree that library media does not pay enough attention to lesbigay issues $(P=.0323)$; less likely to agree that it pays too much attention to lesbigay issues $(P=.0076)$; less likely to be offended by an American Libraries cover featuring openly lesbigay librarians $(P=.0134)$; and more likely to be affected by an issue of American Libraries devoted to lesbigay concerns $(P=.0006)$. Graduates of schools in certain regions were more likely to agree that library media did not pay enough attention to lesbigay issues: mean responses from the Southeast, the West, and Canada showed the greatest differences from the total sample mean responses in this direction. It is problematic to draw conclusions based on these regional differences, however, given the fact that western programs were underrepresented in the present survey.

The M.L.I.S./M.L.S. Curriculum

Six items referred to the coverage of social responsibilities generally (item 3, 8, 17) and coverage of multiculturalism (item 29), women's issues (item 5), and lesbigay issues (item 31) in the curricula of M.L.I.S. and M.L.S. programs (see table 3). Two of these items (8 and 31) asked respondents to rate coverage of social responsibilities generally and les- 
TABLE 3

1993 LiS Graduates' Perceptions of Course Content Related to Social ResPonsibilities IsSUes and Gay and Lesbian IsSUes

\begin{tabular}{|c|c|c|}
\hline Course & $\begin{array}{l}\text { Social Issues } \\
\text { Covered }\end{array}$ & $\begin{array}{l}\text { Gay/Lesbian } \\
\text { Issues Covered }\end{array}$ \\
\hline \multicolumn{3}{|l|}{ Foundations: } \\
\hline Agree & $291(62.6)$ & $130(28.0)$ \\
\hline Disagree or no response (NR) & $174(37.4)$ & $335(72.0)$ \\
\hline \multicolumn{3}{|l|}{ Research methods: } \\
\hline Agree & $117(25.2)$ & $38 \quad(8.2)$ \\
\hline Disagree/NR & $348(74.8)$ & $427(91.8)$ \\
\hline \multicolumn{3}{|l|}{ Reference: } \\
\hline Agree & $259(55.7)$ & $119(25.6)$ \\
\hline Disagree/NR & $206(44.3)$ & $346(74.4)$ \\
\hline \multicolumn{3}{|l|}{ Technical services: } \\
\hline Agree & $65(14.0)$ & $25 \quad(5.4)$ \\
\hline Disagree/NR & $400(86.0)$ & $440(94.6)$ \\
\hline \multicolumn{3}{|l|}{ Library type: } \\
\hline Agree & $174(37.4)$ & $90(19.4)$ \\
\hline Disagree/NR & $291(62.6)$ & $375(80.6)$ \\
\hline \multicolumn{3}{|l|}{ Diversity course: } \\
\hline Agree & $125(26.9)$ & $64(13.8)$ \\
\hline Disagree/NR & $340(73.1)$ & $401(86.2)$ \\
\hline \multicolumn{3}{|l|}{ Other course: } \\
\hline Agree & $130(28.0)$ & $77(16.6)$ \\
\hline Disagree/NR & $355(72.0)$ & $388(83.4)$ \\
\hline \multicolumn{3}{|l|}{ Collection management: } \\
\hline Agree & $47(10.1)$ & $24 \quad(5.2)$ \\
\hline Disagree/NR & $418(89.9)$ & $441(94.8)$ \\
\hline \multicolumn{3}{|l|}{ Bibliography/materials: } \\
\hline Agree & $15 \quad(3.2)$ & $23 \quad(4.9)$ \\
\hline Disagree/NR & $450(96.8)$ & $442(95.1)$ \\
\hline \multicolumn{3}{|l|}{ Administration/management: } \\
\hline Agree & $20(40.3)$ & $10 \quad(2.2)$ \\
\hline Disagree/NR & $445(95.7)$ & $455(97.8)$ \\
\hline \multicolumn{3}{|l|}{ Intellectual freedom/ethics: } \\
\hline Agree & $12(2.6)$ & $6 \quad(1.3)$ \\
\hline Disagree & $453(97.4)$ & $459(98.7)$ \\
\hline \multicolumn{3}{|l|}{ Not discussed at all: } \\
\hline Agree & $42 \quad(9.0)$ & $222(47.7)$ \\
\hline Disagree/NR & $423(91.0)$ & $243(52.2)$ \\
\hline
\end{tabular}

Note. $-N=465$; percentages are given in parentheses. 
bigay issues specifically in designated courses. The visual presentation of items 8 and 31 relating to courses in which social responsibilities and lesbigay issues were covered created problems. We decided to use the Likert format with these items to account for shades of coverage; as in other questions, the neutral response "both agree and disagree" was difficult to interpret when data analysis began, and we finally decided to collapse the categories "strongly agree," "agree," and "both agree and disagree" to indicate that the topic was covered in some manner in the course. As reported above, the Likert-scale responses confused some subjects on these questions, and some apparently did not notice the option "not discussed at all," although it was clear in some cases that the issues had not been covered. Respondents to items 8 and 31 who marked "other" courses were also asked to supply titles of courses in which these issues were covered. Because of the nonresponse rate and some apparent confusion on items 8 and 31 , only descriptive statistics are reported for these two items.

Over half of the respondents (61.3 percent) agreed or strongly agreed that their M.L.I.S./M.L.S. education introduced them to the concept of social responsibilities of librarians, and only 21.7 percent disagreed or strongly disagreed. This finding would seem to underscore the need for coverage of these issues in M.L.I.S./M.L.S. curricula, although it should be tempered with the knowledge that not all social responsibilities issues receive equal coverage at the present time. For example, 54.9 percent unequivocally agreed that multicultural diversity had received some special emphasis in the curriculum, while only 25.8 percent agreed that women's issues had received similar emphasis. While only 9 percent agreed that women's issues were "not discussed at all" in the item that asked respondents to rate coverage of these issues in specific courses, 47.7 percent agreed that lesbigay issues were not covered at all.

Students usually learned about social responsibilities (item 8 ) in foundations courses (62.6 percent) or in public service courses like reference (55.7 percent). They also discussed them in some administration/ management courses in dealing with personnel concerns and clientele base (40.3 percent), or in library courses ( 37.3 percent) where library constituency was an appropriate topic. Only 26.2 percent marked a "diversity-type" course, although comments that accompanied this choice seemed to indicate that not many such electives were currently offered. Students sometimes learned about social responsibilities in research methods courses (25.2 percent) and, more rarely, in technical services courses (14.0 percent) - a finding that is surprising given the effort expended in recent decades on revising subject headings for groups like specific native tribes, women, and lesbigays. Only 2.6 percent learned about social responsibilities in a specific intellectual freedom/ethics course. 
As for lesbigay issues (item 31), coverage is at best uneven. Approximately a quarter (26 percent) learned about lesbigay issues in foundations courses, and a quarter ( 25 percent) heard about them in reference courses. In a fifth of cases (19.9 percent) students learned about the concerns of lesbigays in a library-type course where specific clientele needs were discussed. Only half as many persons who agreed they learned about social responsibilities in a diversity-type course learned about lesbigay issues in such a course (16.6 percent), and they only occasionally learned about them in research methods ( 8.2 percent), technical services (5.4 percent), collection management (5.2 percent), or intellectual freedom/ethics courses ( 1.2 percent). Two respondents opined that coverage of lesbigay issues occurred only because their professor was "gay" and had an interest in the subject. Given the apparent lack of consistency in coverage of lesbigay issues, when they are covered at all, it is perhaps encouraging that research methods courses occasionally take up the subject, since from the viewpoint of methodology, and the identification of appropriate and researchable questions, much work obviously remains to be done.

\section{Qualitative Comments}

Open-ended comments, ranging from terse statements to essays, were received from seventy-seven individuals ( 16.6 percent). It is not the purpose of this report to provide a detailed analysis of these comments but, rather, to provide a characterization of those most relevant to social responsibilities and lesbigay issues particularly as they relate to the curricula of M.L.I.S./M.L.S. programs and to the profession. Some comments were frankly tangential to the study. Several people expounded on issues they thought deserved fuller coverage in the curriculum that were not covered by the survey-for example, environmental issues, persons with physical disabilities, world poverty and hunger, and unemployment. Others discounted the lesbigay focus and advocated addressing women's issues first ("Too much coverage of gay and lesbian issues in the media. Let's work on breaking the glass ceiling"). Other comments were useful in clarifying defects in the survey, as in the case of one school media specialist who marked "both agree and disagree" for three items she did not know how to answer, and in the cases of persons who objected to the use of vague, ambiguous, or "loaded" terms like "liberal," "conservative," and "political correctness"; in identifying areas that deserve further study, as did one southern female librarian who remarked that she really had "no idea what effect Affirmative Action/Equal Opportunity Act has on the library profession"; and in tracking and clarifying the conflicted, if somewhat virulent, reactions the survey provoked ("I feel that the gay rights movement has beaten the issue into the ground, and like Whitewater, I'm sick of hearing about 
it and wish that life would move on, and some strength of character emerge to move forward from self-pity and spoiled child tantrums").

From qualitative comments, it is clear that some subjects had been tracking lesbigay issues as covered by the library media, and that this may have accounted for some of their negative reactions. One person, for example, felt that "the lobby-type power" wielded by ALA in canceling the 1998 Denver conference because of Colorado's antilesbigay initiative was "scary and heavy-handed." One southern female (quoted above), commented that the lesbigay cover on 1992 American Libraries "coupled with political activism (pro-gay/lesbian) in the national office has caused many members to drop off," especially in the "conservative South." She also mentioned high membership fees as a factor in accounting for these feelings, as "some feel that by paying annual dues they are contributing to a political cause they do not support." Ironically, total responses received from southeastern M.L.I.S./M.L.S. graduates supported greater coverage of lesbigay issues in the library media (see statistical analysis and accompanying caveat above).

Some graduates felt daunted by the prospect of initiating an active program in collection of lesbigay materials after graduation, however, and they were as likely to be intimidated by their colleagues as their patrons. One librarian in a New York City public library branch was surrounded by coworkers who were "vehemently anti-gay. One actually said, 'What would happen to the population if everyone turned gay?' and seemed sincerely threatened by the lifestyle." Another whose "big Eight" M.L.I.S./M.L.S. program "did not really address gay and lesbian issues" felt unprepared for the "flap" over formation of a gay and lesbian club at a community college, and, under the direction of the librarian, was assembling a list of titles "in case community members come into the library to challenge us" about lesbigay holdings.

As for coverage of lesbigay issues in the curriculum, while one marked the item relating to discussion of lesbigay issues "not discussed at all," and appended the epithet "Thank God!" several other subjects, all heterosexual, wrote comments supportive of the present study, complimented its design, and/or thanked us for giving the opportunity to respond to these issues. Typical was the following: "I cannot emphasize how little attention the topic received in my library education-the continued omission of the subject in required courses is a great disservice to information professionals of the future. Thank you for conducting the survey-I hope it wakes up some graduate school deans out there!"

Graduates of M.L.I.S./M.L.S. programs on the whole felt confused about the relationship between social activism and library professionalism, questioned the definition of social activism, or adopted passive approaches to social issues. In other words, while they may "personally" 
espouse liberal causes (which, to judge from their self-selected social orientation in table 2 , the majority apparently do), they believe that there is an inherent conflict in active programming to support such a cause outside routine collection development. One counseled that "if professional librarians wish to campaign for social causes outside the realm of libraries-e.g., free distribution of condoms to fight the spread of AIDS-they should do so as private citizens (I say as one who believes in the idea of distributing condoms)." On the other hand, some graduates recognized the paucity of actual research on lesbigay issues in the profession, and the fact that many librarians confuse "any discussion of gay and lesbian issues" with social activism for lesbigay rights.

\section{Discussion and Conclusions}

The present survey is exploratory in nature and deals with issues and factors that are in themselves difficult to isolate, discuss dispassionately, or study within the somewhat narrow parameters of traditional social scientific research protocols without great expense. Some colleagues suggested, for example, that focus group interviews rather than the written questionnaire would be a more appropriate venue for exploration of the topic. While also a possible approach, we felt that the topic could not be turned over to a discussion-group leader at each site without adequate training, given the nature of the subject studied. How would graduates be assembled at each site? How could researchers ensure that someone would be present to defuse gay- and straight-, maleand female-, liberal- and conservative-bashing? Who but ourselves could clarify terminology that safely passed pretesting but presented problems to some respondents? Moreover, the questionnaire offers one incontestable advantage over focus groups in researching controversial topics: privacy. While the criticisms received were in many cases valid, we reasoned from the beginning that the primary purpose of the survey was to open discussion on a previously unexplored topic rather than to create a flawless model for future researchers. As lesbian researcher Lynn Keenaghan has noted, there is no sense in closing a door that is not yet opened, whether that door leads to the private "closets" of research subjects' personal lives or presents an exit from the positivist assumptions that have discouraged lesbigay and feminist research and further served to institutionalize discrimination [43, pp. 86-89]. In other words, would it have been better not to conduct the survey at all? We believed not. Many so-called unorthodox techniques have to be tested before the limits of social research can be ascertained, and in no other research area is this fact more evident than that which covers sensitive topics 
[50, pp. 1-43]. Oral history and other qualitative techniques have been refined in recent years, for example, to incorporate reader-response theory; no longer is the "interpretation" of a scientific "authority" (the researcher) deemed necessary to lend credence or validity to life-history narratives ([51] incorporates this view; [52] describes it; [53] represents the traditional approach). It is the historians' skills that prove most valuable in checking out disputed facts in oral histories, and the less obtrusively these "corrections" are made, the better, since how a person remembers events may be as important as what they remember. Certainly on a topic such as lesbigay issues in librarianship, on which there is virtually no research and to which there is much conscious and unconscious resistance, at least some research conventions spawned by the "straightgeist" [54] have to be muted so that a minimum of baseline data can be established.

One readily apparent finding of the survey is that there is no consistency in approach to the treatment of social issues generally and lesbigay concerns specifically in M.L.I.S./M.L.S. curricula, and these findings are bolstered by qualitative comments. In part, these discrepancies reflect a curriculum already crowded with new technology courses. Three individuals were openly contemptuous of their library education, claiming that they learned absolutely nothing new or useful to them, and one characterized hers as a "pleasant waste of time." The majority of those who made comments seemed generally supportive of the programs they had attended.

Probably the most important finding of the survey is that self-selected social orientation (for example, "liberal," "conservative"), more than any other factor, determines how respondents react to social responsibilities, including lesbigay issues (see table 4). There were significant differences in the responses to twenty-two statements depending on self-described social orientation; on twelve items depending on sex of respondent; eleven items depending on sexual orientation of respondent; on seven items depending on whether or not the respondent had known someone who died of AIDS; five by library type; and four by age. Another finding, expected but now confirmed, is that general issues of lesbigay status and questions about lesbigay materials in the library are by far the most volatile of the issues covered by the present survey. Responses to nineteen items in this category show statistically significant differences. The treatment of lesbigay issues by the library media account for statistically significant differences on thirteen items, and general social responsibilities (twelve items) and diversity/political correctness (eleven items) account for nearly as many differences.

In reporting statistical data, detailed analysis has been given only for the factors of sexual orientation, although it is worth emphasizing that 
TABLE 4

Number of Questionnaire Items for Which Selected Demographic Variables Produce. Significant Differences

\begin{tabular}{|c|c|c|c|c|c|c|c|c|}
\hline Item Set & Sex & $\begin{array}{c}\text { Sexual } \\
\text { Orientation }\end{array}$ & $\begin{array}{c}\text { Social } \\
\text { Orientation }\end{array}$ & Age & $\begin{array}{l}\text { Library } \\
\text { Type }\end{array}$ & $\begin{array}{c}\text { Knew } \\
\text { AIDS } \\
\text { Victim }\end{array}$ & $\begin{array}{l}\text { Region } \\
\text { of School }\end{array}$ & $\begin{array}{l}\text { Total } \\
\text { for Items }\end{array}$ \\
\hline Social responsibilities items ( 7 items) & $\cdots$ & 1 & 6 & 1 & 1 & 1 & 2 & 12 \\
\hline Diversity/political correctness items (4 items) & 1 & 3 & 4 & 1 & $\cdots$ & 1 & 1 & 11 \\
\hline Womens issues/EO/AA items (5 items) & 4 & $\cdots$ & 3 & $\cdots$ & $\cdots$ & 2 & $\cdots$ & 9 \\
\hline Lesbigay issues ( 6 items) & 4 & 3 & 4 & $\cdots$ & 2 & 2 & 4 & 19 \\
\hline Lesbigay media items (5 items) & 1 & 4 & 4 & 1 & 1 & 1 & 1 & 13 \\
\hline $\begin{array}{l}\text { Social responsibilities, women's, and lesbigay } \\
\text { in curriculum ( } 4 \text { items) }\end{array}$ & 1 & $\cdots$ & 1 & 1 & 1 & $\cdots$ & $\cdots$ & 4 \\
\hline Total (31 items) & 11 & 11 & 22 & 4 & 5 & 7 & 8 & 68 \\
\hline
\end{tabular}


twice as many items are likely to be answered in a given direction based on self-selected social orientation, and for seventeen of these items, $P$ $=.0000$. In itself, this finding suggests that discussion of social issues, including sexual orientation, is highly politicized in the current social environment. This should temper interpretation of claims of librarian "neutrality" found in many of the open-ended comments given separately in the survey. Whatever the claims of neutrality in professionalism, attitudes and perceptions are apparently affected by "social orientation" labels along the liberal-conservative spectrum. However, much as the respondents might seek an ideal neutrality, their professional attitudes are shaped by social forces. Librarians' response to social issues is a topic that deserves extensive future study, especially since it has apparently been ignored in favor of "more pressing library issues"; also, the sparsity of research in related areas such as authoritarian attitudes of librarians vis-à-vis censorship merits attention, since in library education the information is quite dated [55], and the social climate has altered dramatically in the past quarter century.

Thus, while lesbigay issues may not be the most urgent concern facing libraries, even in terms of collection development, they certainly deserve some mention in the pantheon of worthy social concerns facing librarians in their dealings with the public and with their colleagues, and a great deal more intelligent analysis than has yet been forthcoming. Unfortunately, the empty argument that homosexuality is a volatile issue among many segments of the population and therefore damages the librarian image will not make the issue go away. Lesbigays are a vocal minority in society, and the general population confuses media coverage of the more sensational or colorful aspects of lesbigay life-such as the San Francisco Gay Pride Day Parade, replete with drag queens, "dykes on bikes," bearded men in nun's habits, and other expressive or exhibitionist behavior - with the struggles of a minority for acceptance, equal protection under law, and freedom from harassment and ignominy in the workplace and in the community [47]. While librarians give at least passing mention to lesbigay clients, they rarely connect their concerns to the daily lives of their lesbigay colleagues-if, indeed, they even know or care who these individuals are. It cannot be denied that some lesbigay librarians fear being "discovered," since their livelihoods, if not their careers, may be at stake.

On the whole, library school graduates of 1993 are theoretically supportive of lesbigays as an embattled minority, although some of them would rather confine thinking about lesbigay issues to the home news hour rather than deal with these issues in their professional lives. Libraries for some represent a safe haven from the squalor of endless talkshow setups with representatives of the lesbigay community who would 
be, by any account, lesbigay or straight, unusual (such as the Oprah Winfrey-Sally Jesse Raphael sideshows). Library education curricula are crowded already and may not be able to concentrate on social issues any more than they already do in courses such as foundations, management, and reference. What they can do is refocus discussion in these courses to incorporate lesbigay issues routinely, along with other groups in the social spectrum who have special needs and are perhaps receiving only the theoretical benefits of a democratic society while they continue to experience intentional or subliminal discrimination in their daily lives.

One of the promises implicit in a democratic society is the right of individuals to receive equal treatment under the law, and one of the promises tendered by the library profession in this society is that all persons will be able to receive the information they need when it is needed. It is hard to understand how the latter scenario can prevail if librarians are unfamiliar with their lesbigay clientele and coworkers or are hostile to them. While only a handful of responses received to this survey recount incidents of such hostility, or express such hostility, they are pervasive enough to warrant greater examination of what professional librarians learn in their M.L.I.S./M.L.S. programs. The fact that some programs choose to ignore lesbigay issues entirely may in part reflect the paucity of serious research on the subject, or the ignorance of instructors about lesbigay research needs, or the reluctance of lesbigay researchers to be tagged throughout their career for having pursued what some consider to be a trivially dangerous subject.

One straight midwestern library school professor commented to us that he had tried repeatedly to persuade lesbigay students who are "out" to select a lesbigay research topic, to no avail; that conversation was, in fact, the genesis for this study. It is doubtful that lesbigay librarians will receive much support for this line of research in the near future, unless their concerns are validated in M.L.I.S./M.L.S. curricula and by professors. One lesbian Canadian student expressed this need succinctly: "Thank you for your work in this area. As a gay member of this profession, I have often chosen to keep quiet about social responsibilities in work environments and in the classroom setting. Unfortunately, M.L.I.S. degrees focus on theory and technical abilities while ignoring to a great extent the social responsibilities of future professionals. . . . Open discussions are few ... magistral courses are many! I have much to learn about my gayness (as it is quite new to me) however I feel that work [on lesbigay issues] is indeed important and necessary in the area of LIS degree curricula."

The profession exists today without a view of the overall attitudes of library professionals toward the social responsibility mandate. One recent letter to American Libraries [56] has suggested that opposition to 
social activism in past years has come from two camps: (1) those librarians who oppose lesbigay interests generally and therefore deny the validity of lesbigay claims in the professional context and (2) those who have no particular aversion to lesbigays within the profession but feel that social activism with political implications detracts from the "proper" sphere of professional practice. Such impressions as these should be ascertained and explored further, for they have profound implications for future discussions of all social issues within the profession.

More important, library educators need more feedback on what, if any, orientation students receive to librarianship's social values. While it may be assumed that intellectual freedom should be important to all beginning professionals, definitions of that term among assorted individuals yield more complex and less monolithic definitions than have been previously supposed. This study presents one interpretation of attitudes toward social issues expressed by beginning professionals, a group whose personal profile can be projected to be different from their 1960s counterparts. In a slightly different sense, however, these attitudes conform to Alice Bryan's classic characterization of public librarian attitudes. According to Bryan, public librarians reflected majority public sentiment in endorsement of specific legislation, whatever its liberal-conservative orientation. ${ }^{13}$ At the same time, these librarians exhibited lower-than-average norms in (social) "leadership and selfconfidence." Like many respondents to the present survey, they expressed concern that "the library schools and their faculties lack understanding of the educational and social objectives" of libraries [ 1 , pp. 53-54, 75]. A present-day (modified) replication of Bryan's study is greatly needed, if for no other reason than that we know so little about who librarians are and how they have changed in response to a basically transformed society. A study such as Bryan's would be difficult to conduct today, given recent bureaucratic and legalistic interpretations of confidentiality in social research, and these restrictions should be investigated and assailed in research methods and archives courses, in ALA, and in the courts. Equally important is the need for a study of the minority who are isolated on the conservative end of the present attitudinal survey, for they also have often been unfairly stereotyped (as zealots, and much worse). As one respondent explained, referring to his work in a denominational school, "I was a little amazed at receiving this survey. My religious 'affiliation' is in the minority and my working

13. For example, Bryan measured their attitudes toward the Taft-Hartley Act, which restricted the power of labor unions and required a loyalty oath disavowing membership in the Communist Party; the Marshall Plan, which extended postwar foreign aid; and the lifting of tariffs. 
situation is far different from what the public views as 'socially' acceptable."

It remains to be seen whether or not librarians will indeed become professional leaders in welcoming research that is lesbigay-friendly (even in a reactionary social environment), or whether they will recognize lesbigay rights only as forced to by legal precedent. To judge from the responses received in the present survey, the personal is indeed political (as Sartre once observed), and professional, too. The neutral position reflects a professional political stance as much as do liberal or conservative stances. How much this "neutral" stance represents a desirable attitude in the 1990s-an age in which some large corporations seem to be leading the way in lesbigay-friendly policies and work situations - is a question that library educators will need to address as the disparity between the rhetoric and the reality of librarians' work situation comes to the attention of outside observers.

\section{Appendix}

Social Responsibilities Survey

For each of the following statements below circle one of the numbers in the right-hand column using the following key:

$$
\begin{array}{lc}
1=\text { strongly agree with statement } & 4=\text { disagree with statement } \\
2=\text { agree with statement } & 5=\text { strongly disagree with } \\
3=\text { both agree and disagree } & \text { statement }
\end{array}
$$

1. Professionals should remain aloof from social activism.

2. The library profession is more socially progressive than most professions.

3. My education in librarianship introduced me to the concepts of librarians' social responsibility.

4. Libraries and librarians have a responsibility to address social issues.

5. Women's issues received some special emphasis in my LIS curriculum.

6. Materials on controversial topics such as gay and lesbian issues should be kept off open shelves in communities where there is a strong anti-gay sentiment.

12345

7. The library media distorts gay and lesbian issues within the library profession.

122345

8. I learned most about social responsibilities of librarians through the following courses: 
$\begin{array}{llllllllllll}\text { Foundations } & 1 & 2 & 3 & 4 & 5 & \text { Technical Services } & 1 & 2 & 3 & 4 & 5 \\ \text { Research Methods } & 1 & 2 & 3 & 4 & 5 & \text { Type-library course } & 1 & 2 & 3 & 4 & 5 \\ \text { Reference } & 1 & 2 & 3 & 4 & 5 & \text { Diversity course } & 1 & 2 & 3 & 4 & 5\end{array}$

$\begin{array}{llllll}\text { Other } & 1 & 2 & 3 & 4 & 5 \\ \text { Not discussed at all } & 1 & 2 & 3 & 4 & 5\end{array}$

9. Public libraries should adhere to the philosophy "something to offend (and satisfy) everyone."

12345

10. Gay and lesbian issues should be addressed through collection development in all areas of the library (fiction, non-fiction, reference, etc.).

11. "Political correctness" is a danger to freedom of speech.

$\begin{array}{lllll}1 & 2 & 3 & 4 & 5\end{array}$

12. Affirmative Action/Equal Opportunity legislation has had a negative effect on the library and information professions. $123 \quad 345$

13. There are just too many special interest groups and minority groups competing for attention in our society.

$123 \quad 4 \quad 5$

14. Within the library and information profession, the library media doesn't pay enough attention to gay and lesbian issues.

12345

15. I would be offended by an American Libraries cover featuring openly gay and lesbian librarians.

12345

16. Affirmative Action/Equal Opportunity legislation has had no discernible effect on the library and information profession.

123345

17. Social responsibilities received some special emphasis in my LIS curriculum.

12345

18. The dangers of a philosophy of "political correctness" are greatly exaggerated by the media.

12345

19. I would not be affected one way or another by an issue of American Libraries devoted to problems and concerns of gay librarians and library clients. $\quad 123445$

20. I disagree with the premise of pro-gay and lesbian literature and would only purchase these titles if the community requested them.

$\begin{array}{lllll}1 & 2 & 3 & 4 & 5\end{array}$

21. Library and information professionals have adequately addressed social and political issues.

12345

22. If I were responsible for collection development in a public library, I would have acquired children's titles dealing with gay and lesbian issues such as Heather Has Two Mommies and Daddy's Roommate-if they were the best titles of their type available.

12345

23. Affirmative Action/Equal Opportunity legislation has had a positive effect on the library and information professions. $\quad 12345$

24. There is a higher percentage of gays and lesbians in the library and information profession than in the society at large.

122345

25. I was aware of the social responsibility aspect of librarianship before entering an LIS program. 
26. A philosophy of "political correctness" is essential for the protection of the rights of some minority groups. 12345

27. Social activism is intrinsic to the exercise of First Amendment rights in a democratic society.

$\begin{array}{lllll}1 & 2 & 3 & 4 & 5\end{array}$

28. The library media pays too much attention to gay and lesbian issues in the library profession.

$123 \quad 45$

29. Multicultural diversity received some special emphasis in my LIS curriculum.

122345

30. Women's issues have received too much attention in library literature.

31. Gay and lesbian library issues received some emphasis in the following courses:

Foundations $\quad \begin{array}{llllllllll}1 & 2 & 3 & 4 & 5 & \text { Technical Services } \quad 123 & 1 & 2 & 4\end{array}$

Research Methods $\quad \begin{array}{llllllllllll}1 & 2 & 3 & 4 & 5 & \text { Type-library course } & 1 & 2 & 3 & 4 & 5\end{array}$

Reference

$\begin{array}{lllllllllll}1 & 2 & 3 & 4 & 5 & \text { Diversity course } & 1 & 2 & 3 & 4 & 5\end{array}$
Other
$\begin{array}{llllll}1 & 2 & 3 & 4 & 5\end{array}$
Not discussed at all $\quad \begin{array}{lllll}1 & 2 & 3 & 4 & 5\end{array}$

32. Library materials on controversial topics such as gay and lesbian issues should be sequestered to prevent theft or defacement.

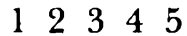

33. Women's issues have not been adequately addressed by the library and information profession.

\section{PERSONAL AND PROFESSIONAL DATA}

For each of the following questions, check any categories which apply at the present time:

PERSONAL:

SEX: Female

AgE: 21-29 $46-49$

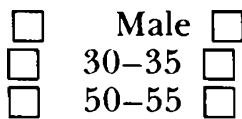

$36-39$

56 or older

STATE OF BirTh (if foreign, country):

ETHNICITY:

Native American or Alaskan Native

Black, Non-Hispanic

White, Non-Hispanic

Asian or Pacific Islander

Hispanic

Other:

Marital Status: Single $\square \quad$ Married $\square \quad$ Living with partner (Check one)

Sexual Orientation:

Straight $\square \quad$ Gay or lesbian $\square \quad$ Bisexual or other $\square$ (Check one)

Social Orientation: I describe myself as socially: (Check one) radically progressive $\square$ liberal $\square$ moderate conservative $\square$ radically conservative

I have personally known someone who has died of AIDS: Yes $\square \quad$ No 


\section{EDUCATION:}

Undergraduate Major: __ Year Degree Received:

Education OTHER THAN LIS: (Please check any areas which apply)

Master's degree in another subject area

Name subject area:

Doctorate in other subject field

Other (Please specify):

LENGTH OF LIS EDUCATION:

What year/semester did you begin your LIS degree work?

PREVIOUS WORK (PRIOR TO LIS MASTER'S DEGREE):

Previous Library EXPerience:

Number of years as a professional

Number of years as a paraprofessional

PRESENT WORK:

LIBRARY TYPE: Academic $\square$ Public $\square$ School Library Media Special $\square$ Non-LIS Position

No job at present

Position Function:

Othe

Select one which best describes your current responsibilities:

Administration $\square$

Adult Services

Reference Other Public Services Youth Services

Cataloging $\square$ Acquisitions

Collection Development

School Library Media $\square$ Other (Please describe):

N/A

Number of Years in Present Position:

In what type of library did you originally want to work?

If applicable, why did you change type of library?

THANK YOU FOR YOUR ASSISTANCE. PLEASE USE THE BACK OF THESE PAGES OR ATTACH OTHERS TO MAKE ANY ADDITIONAL COMMENTS YOU MAY HAVE ABOUT THIS SURVEY OR THE SOCIAL RESPONSIBILITY ROLE OF LIBRARIES OR LIBRARIANSHIP.

\section{REFERENCES}

1. Bryan, Alice I. The Public Librarian: A Report of the Public Librany Inquiry. New York: Columbia University Press, 1952.

2. Wilson, Patrick. The American Public Library and the Problem of Purpose. New York: Greenwood, 1988. 
3. Bundy, Mary Lee, and Stielow, Frederick J. Activism in American Librarianship, 19621973. New York: Greenwood, 1987.

4. Boaz, Martha. "The First Responsibility." American Libraries 23 (October 1992): 738.

5. "More on Gay Cover-age" (letters). American Libraries 23 (October 1992): 738.

6. American Libraries, vol. 23 (July/August 1992).

7. Gittings, Barbara. Gays in Library Land: The Gay and Lesbian Task Force of the American Library Association: The First Sixteen Years. Philadelphia: Barbara Gittings, 1990.

8. Dynes, Wayne R., ed. The Encyclopedia of Homosexuality, New York: Garland, 1990.

9. Whitt, Alisa J. "The Information Needs of Lesbians and Bisexual Women." Library and Information Science Research 15 (Summer 1993): 275-88.

10. Hoffman, Susan, and Mintz, Susan. "The Phenomenon of Gay Men in Librarianship." Discussion draft, John F. Kennedy School of Government (Public Policy on Divided Societies, Course M-809), Harvard University, 1987.

11. Carmichael, James V., Jr. "The Gay Librarian: A Comparative Analysis of Attitudes towards Professional Gender Issues." Journal of Homosexuality 30, no. 2 (1995): 1359.

12. Wiegand, Wayne A., ed. The Encyclopedia of Library History. New York: Garland, 1994.

13. Parkinson, Phil. "Greater Expectations: Services to Lesbians and Gay Men." New Zealand Libraries 45 (March 1987): 92-97.

14. Holley, Edward G. Charles Evans: American Bibliographer. Urbana: University of Illinois Press, 1963.

15. Carmichael, James V., Jr. "Ahistoricity and the Library Profession: Perceptions of Biographical Researchers in LIS concerning Research Problems, Practices and Barriers." Journal of Education in Library and Information Science 31 (Summer 1991): 329-56.

16. Thistlethwaite, Polly. "The Lesbian and Gay Past: An Interpretive Battleground." Gay Community News (Boston) 2 (Winter 1995): 10-11, 24.

17. Williams, Christine L. Gender Differences at Work: Women and Men in Nontraditional Occupations. Berkeley and Los Angeles: University of California Press, 1989.

18. Harbeck, Karen M., ed. Coming out of the Classroom Closet: Gay and Lesbian Students, Teachers and Curricula. New York: Harrington Park, 1992.

19. Harsin, Steven D. "Pathfinder: Developing a Gay Identity." Collection Building 11, no. 4 (1992): 31-36.

20. Gough, Cal R., and Greenblatt, Ellen. "Services to Gay and Lesbian Patrons: Examining the Myths." Library Journal 117 ( January 1992): 59-63.

21. Gough, Cal R., and Greenblatt, Ellen, eds. Gay and Lesbian Library Service. New York: McFarland, 1990.

22. Berman, Sanford. The Joy of Cataloging: Essays, Letters and Other Explosions. Phoenix: Oryz, 1981.

23. Pharr, Suzanne. Homophobia: A Weapon of Sexism. Little Rock, Ark.: Chardon, 1988.

24. Hall, Jacquelyn D. Revolt against Chivalry: Jesse Daniel Ames and the Women's Campaign against Lynching. New York: Columbia University Press, 1979.

25. Reinisch, June. The Kinsey Institute New Reports on Sex: What You Must Know to Be Sexually Literate. New York: St. Martin's, 1990.

26. Gonsiorek, John C., and Weinrich, James D. "The Definition and Scope of Homosexuality." In Homosexuality: Research Implications for Public Policy, edited by John C. Gonsiorek and James D. Weinrich. Newbury Park, Calif.: Sage, 1991.

27. Williams, Christine L. Still a Man's World: Men Who Do "Women's Work." Berkeley and Los Angeles: University of California Press, 1995.

28. "Gender Issues Still Need to Be Addressed." Library Personnel News 4 (Fall 1990): $1-2$.

29. Carmichael, James V., Jr. "Gender Issues in the Workplace: Male Librarians Tell Their Side." American Libraries 25 (March 1994): 227-30. 
30. “AMA Bans Discrimination on Sexual Orientation." AAPHR Reporter (Summer 1993), p. 1.

31. "Committee on Women Historians Report on the Lesbian and Gay Historians Survey." Perspectives 31 (April 1993): 13-15.

32. Blythe, John; Boswell, John; Botstein, Leon; Kerrigan, William; and Hitt, Jack. "New Rules about Sex on Campus" (Forum Discussion). Harper's Magazine 287 (September 1993): 33-43.

33. Broderick, Dorothy M. "Moral Conflict and the Survival of the Public Library." American Libraries 24 (May 1993): 447-48.

34. Broderick, Dorothy M. "Defending Gay Librarians." Wilson Library Bulletin 49 (September 1974): 31-32.

35. Broderick, Dorothy M. "Free U." Booklegger Magazine 1 (May/June 1974): 37-39.

36. "With Malice towards Some" (editorial). New Yorker 67 (October 26, 1992): 5-6.

37. "Clearances" (editorial). New Yorker 68 (February 15, 1993): 4-6.

38. "Gays under Fire." Newsweek (September 14, 1992): 34-40.

39. Gates, Henry L., Jr. "Backlash?" New Yorker 69 (May 17, 1993): 42-44.

40. Berry, John; Fiakoff, Francine; St. Lifer, Evan; and Rogers, Michael. "Under Protest: ALA Midwinter in Denver." Library Journal 118 (March 1, 1993): 32-38.

41. Gaughan, Thomas M. "The Last Socially Acceptable Prejudice" (editorial). American Libraries 23 (September 1992): 612.

42. Sineath, Timothy W., ed. ALISE Library and Information Science Education Statistical Report. Raleigh, N.C.: Association for Library and Information Science, 1993.

43. Keenaghan, Lynn. "Lost in a 'Straight' Reality: Lesbians and Gay Men in Social Research." In Re-thinking Social Research: Anti-discriminatory Approaches to Research Methodology, edited by Beth Humphries and Carole Truman. Aldershot: Avebury, 1994.

44. Carmichael, James V., Jr. "The Male Librarian and the Feminine Image: A Survey of Stereotype, Status and Gender Perceptions." Library and Information Science Research 14 (October-December 1992): 411-46.

45. Harry, Joseph, and Lovely, Robert. "Gay Marriages and Communities of Sexual Orientation." In Sociology of Homosexuality, edited by Wayne R. Dynes and Stephen Donaldson. New York: Garland, 1992.

46. Miller, Brian. "Adult Sexual Resocialization: Adjustments towards a Stigmatized Identity." In Sociology of Homosexuality, edited by Wayne R. Dynes and Stephen Donaldson. New York: Garland, 1992.

47. Bawer, Bruce. A Place at the Table: The Gay Individual in American Society. New York: Poseidon, 1994.

48. Malitz, Gerald A. A Classification of Instructional Programs. Washington, D.C.: GPO, 1987.

49. Thistlethwaite, Polly. "GLTF Indexing Project Update," GLTF Newsletter 4 (Fall 1992): 7.

50. Lee, Raymond M. Doing Research on Sensitive Topics. New York: Sage, 1993.

51. Casey, Kathleen. I Answer with My Life: Life Histories of Women Teachers Working for Social Change. New York: Routledge, 1993.

$: \rightarrow$ Casey, Kathleen. "The New Narrative Research in Education." Review of Research in Education 21 (1995-96): 211-53.

53. Sheehan, Susan. Life for Me Ain't Been No Crystal Stair. New York: Pantheon, 1993.

54. Baker, Nicholson. "Lost Youth." London Review of Books 16 (June 19, 1994): 6.

55. Busha, Charles H. "Student Attitudes toward Censorship and Authoritarianism." Journal of Education for Librarianship 11 (Fall 1970): 118-36.

56. Coan, Cindy. "Gay Rights Is a Professional Issue" (letter). American Libraries 24 (September 1993): 700. 